\title{
On the Bilingual Teaching in College Mathematics
}

\author{
Berlin Yu (Corresponding author) \\ Faculty of Mathematics and Physics, Huaiyin Institute of Technology \\ Huaian, Jiangsu 223003, P. R. China \\ E-mail: berlin.yu@gmail.com
}

Hong Cheng

Office of Teaching Affairs, Huaiyin Institute of Technology

Huaian, Jiangsu 223003, P. R. China

E-mail: tkggja@126.com

$\begin{array}{ll}\text { Received: October 10, } 2011 & \text { Accepted: December 2, 2011 } \\ \text { doi:10.5430/jct.v1n1p2 } & \text { URL: http://dx.doi.org/10.5430/jct.v1n1p2 }\end{array}$

The research is financed by the Teaching and Learning Research Fund of Huaiyin Institute of Technology (JYB201109).

\begin{abstract}
In this paper, after a brief discussion of historical background of the bilingual teaching in college mathematics, we analyze the difficulties in bilingual teaching of college mathematics firstly. Various approaches and methods that have been put into our bilingual teaching practice to overcome those difficulties are explored in detail. Finally, grades of students indicate that our reform attempts are effective.
\end{abstract}

Keywords: Bilingual teaching, Modern educational technology, Teaching method

\section{Introduction}

The term, bilingual teaching, is defined as the use of a second or foreign language in school for the teaching of content subjects in the Longman Dictionary of Language Teaching and Applied Linguistics [1]. We always think it is a teaching method in two different languages. In general, it uses the native language and takes English as a second language. The common goal for bilingual teaching is to utilize the students' native language for both English acquisition and academic learning in all subjects. Take the Chinese students as an example, they usually think that the bilingual teaching is a teaching and learning model that may contains the English textbook, the homework written in English, examination in English, and communication in English, etc.

With the continual development of China reform and opening, and the development of economic globalization, the communication among different cultures is continually deepened and the development trend of educational internationalization occurs. The application of new technology and the development of long-distance education bring intensive concussion to the higher education of China, and that largely improves the research and practice about education policy, teaching method and course offering in China. To adapt social demand for the talent cultivation in higher colleges and universities, we need continually enhancing the teaching quality of the undergraduate education. In 2001, China Ministry of Education started the "Bilingual Teaching Course Reform Plan" to improve the work of bilingual teaching reform construction.

In accordance with the requirement of the Ministry of Education, many universities and colleges have begun or are beginning to adopt bilingual teaching of non-English-oriented courses. And there are considerable literatures about this topic; see, e.g., [2-6].

In 2001, under the support of Huaiyin Institute of Technology, we take an active part in the research and practice of bilingual teaching in some fundamental or professional curriculums. Especially, we set the college mathematics course in the form of bilingual teaching for students in the department of English. It is well known that college mathematics is one of the most important and fundamental courses for college students. In our institute, college mathematics is a compulsory course and carries at least three credits, especially for those students majoring in literature, linguistic and 
other social sciences. In our bilingual curriculum, the teacher is supposed to teach students the concepts and theories of college mathematics, help them to understand the profound mathematical ideas, and thus improve their abilities to think logically and creatively. During this semester, the students' imaginative powers and computation skills should be increased to some extent.

In this paper, based on bilingual teaching experience accrued over the years, we investigate the difficulties in the process of bilingual teaching, and then explore various approaches and methods to instruct bilingual teaching in college mathematics. The grades that our students got indicate that our strategy is effective.

\section{Difficulties in the process of bilingual teaching in college mathematics}

In this section, we address on the difficulties in the traditional bilingual teaching of college mathematics. Generally speaking, there are four aspects to be considered.

Firstly, many students encountered problems in their class because there were a large number of new words or expressions in the English textbook which they had never learnt. In fact, most students in their class needed to improve their listening ability in English in order clearly to understand what they had heard. It was apparent that some of them felt discouraged even to the point of not wanting to study in English any more. As the teacher of this bilingual course, he was obliged to find a way to solve this problem and he attempted to persuade them out of the idea of dropping the study. He had provided the multi-media courseware in both English and Chinese so that every student could access the information whether their English was good or not. He spoke to them in the class in English with Chinese explanation. If the materials in the textbook were too complicated to understand, he preferred to talk about them in Chinese in order that everyone could follow him. If he always gave expressions in English, he was sure that sometimes they could not understand him very well and they would get rather confused.

Secondly, there is an obstacle to communication between teachers and students in bilingual teaching classes. Although most students come from the English department, their listening ability in English for college mathematics still needs to be improved. Even though they have English listening lessons, they do not have the opportunities to listen to English for college mathematics. Most students cannot speak English fluently. When teachers ask questions, they cannot express what they think about them in English. Perhaps they can reply to them in Chinese, but they do not know how to answer them in English. Importantly, students have difficulties in understanding clearly some definitions that teachers have mentioned in English in bilingual teaching classes.

Thirdly, there is a lack of teachers who can teach the bilingual teaching lessons. Nowadays, although there are many teachers with doctorates in universities, most of them do not have the experience of study in a western country and their oral English is not adequate to teach bilingual teaching lessons. Thus the lack of teachers for bilingual teaching lessons is a common phenomenon in universities.

Finally, the bilingual mathematical textbook and the related references are not sufficient. It seems a shortcut to select original textbooks in English to lead the Chinese education to go internationally. But in selecting the suitable textbooks, the actual ability of college students must be weighed carefully.

In China, the foreign original mathematical textbooks are used by many universities. The incompatibility with our students is mainly teaching contents and studying hours. For example, many foreign teaching materials include single variable calculus, multi-variables calculus, curve and surface integrals, the differential equations, the infinite series and analytic geometry. Some textbooks also contain mathematical statistics, matrices, determinants, and so on. But, our teaching objects are major in the social science. Their mathematical knowledge is relatively poor. What's more, as far as those students are concerned, it is impossible to study this mathematical course completely in only one semester.

\section{Bilingual teaching practice in college mathematics}

Differently from the traditional "chalk plus blackboard" type of teaching model, the bilingual teaching of college mathematics is a new teaching model to be further studied or discussed. In the past practical bilingual teaching, we think the bilingual teaching model at least consists of bilingual textbook according with the Chinese students' characteristics, modern teaching technologies and flexible teaching methods.

\subsection{Bilingual mathematical textbook according with the Chinese students' characteristics}

The compilation of English teaching material basically takes the training of the English knowledge structure and lingual ability as the major idea, and there are few English teaching materials of college mathematics, and to really implement bilingual mathematics teaching. We need compile English teaching materials of college mathematics, and it is a complex system engineering which should not only require familiar English and higher mathematics knowledge system, but also 
arrange training of English hearing and reading skills and emphasize the thinking property and novelty property of college mathematics.

Based on those foreign original mathematical textbooks, we write a bilingual mathematical textbook [7] whose contents are much less than the quondam textbooks. This bilingual teaching material mainly contains: functions, limits and continuity, the derivatives and its applications, the integrals, infinite series and an introduction to differential equations.

The most different from those foreign original mathematical textbooks is that we omit the unnecessary multi-variables calculus and the vector algebra. Our approach is intuitive, and we state the results informally. Numerous examples and figures are used in our textbook to amplify each new concept or result in order to facilitate the Chinese students' comprehension of the material.

\subsection{Modern teaching technologies}

In order to optimize the efficiency of classroom bilingual teaching, we combine the traditional teaching methods with modern educational technologies. According to the syllabus' requirements, we develop a multi-media software that can be used in the bilingual teaching of college mathematics. At present, the multi-media teaching has become one of the important teaching models for the bilingual teachers. The modern teaching technologies can not only reduce the time spent in writing on the blackboard, improve teaching efficiency, but also show a number of abstract mathematical concepts, complicated theorems in an intuitive manner, such as graphics, tables, vivid flashes, etc.

For example, in the traditional teaching, mathematical teachers can not display the limit of $f(x)$ at infinity or at the point $x=x_{0}$ intuitively on the blackboard. So the students always feel the concept of $\lim f(x)$ and $\lim f(x)$ much abstractive and then they are confused. The students do not understand the " $\varepsilon-\delta$ "dêtirnition of limit of functions. There are also some students who have difficulty in understanding the relationship between $\varepsilon$ and $\delta$. If we can draw a precise graph by taking advantage of some computer software, such as Mathematica, Power Point, Matlab, etc, we can presented a lively, vivid and beautiful mathematical concept to them. In fact, it arouses their enthusiasm for learning, promotes students' understanding of mathematical knowledge.

\subsection{Bilingual teaching methods}

In our bilingual teaching, a participatory teaching method based on the student-centred idea is used. This method is divided into three stages. The first stage is called "active learning" which requires the students learn the mathematics knowledge independently from the textbook (see [8]). The active learning always takes place at the students' spare time. "Problem solving" is the second stage. In this stage, the students can make use of their acquisitions to solve some basic mathematical or other related problems with the aid of teachers. For instance, after learning the tests of function's monotonicity, the students can use these tests to show some inequalities, and find the maximum or minimum value of the continuous functions on a closed interval.

The final stage, called "Group Studying", is an activity conducted by both the students and the teacher. In this stage, they discuss the physical or geometrical interpretation of the mathematical concept, its backgrounds, and the relationship to other concepts. The students are also asked to explain the problems they have solved in English. Almost all the students have the experience of discussing the mathematical questions in English. In all the stages, teachers and the students can decide how to teach, what to teach according to their viewpoints.

The traditional teaching method, which means that "when the teachers are talking, the students just listen [9]", enables the students not to participate in the teaching process actively. After a long lecture, the students become exhausted. They feel this course is monotonous and uninteresting. On the contrary, the participatory teaching method enables us to learn and get more. On one hand, the students take so active party in the entire teaching process that the students may feel they is not a "receptor" any longer, but a "subject" in the teaching process. On the other hand, we can get feedback promptly by communicating with each others. After determining whether or not the students have learned, we can adjust our teaching plan and approaches. For example, if they don't understand what we taught completely, we will go over the material from a different angle to explain it again. This approach helps to achieve the best teaching results.

\section{Results of the bilingual teaching}

At the end of this semester, all the students should take a closed-book examination. We note that the students must write the correct answer in English on the English paper, although it is difficult for them to do it in that way. After final examination of the bilingual teaching of college mathematics, we analyze all the grades that the students had achieved.

Averagely speaking, from Fig. 1, we can see about $16 \%$ of students scored more than 85 marking (Excellent), $26 \%$ of them scored between 70 to 85 marking (Good), 53\% of them scored between 60 to 70 marking (Satisfied)and only 3\% 
did less than 60 marking (Poor)in recent five years. What is the most important is that all the students think the college mathematics course is no longer abstractive and no more tedious, but an interesting and beautiful science.

\section{Conclusion}

In the article, we have introduced the background and main difficulties of the bilingual teaching of college mathematics. Various approaches and methods that had put into our bilingual teaching practice to overcome these difficulties have explored. And grades of students show that our bilingual teaching of college mathematics is effective.

However, many problems still exist in the bilingual teaching of college mathematics course. Aiming at these difficulties, we will go on studying these problems in the bilingual teaching of college mathematics in the future.

\section{References}

J. Richards (2007). Longman Dictionary of Language Teaching and Applied Linguistics. Beijing: Foreign Language Teaching and Research Press.

Z. Zhang(2003). A Research on the Gain and Cost of Bilingual Teaching of Non-English-Oriented Courses. Teaching English in China, 27(3): 78-79.

B. D. Iacovo(2009). Curriculum Reform and Quality Education in China: an Overview. International Journal of Educational Development, 29: 241-249. http://dx.doi.org/10.1016/j.jjedudev.2008.02.008

X. Wang, Y. Guo. A survey on Bilingual Teaching. Foreign Language Study, 7(2)(2006): 135-136.

X. Xing. Survey and Recommendations on Bilingual Education. Statistics and Consultation, 6 (2006): 73-74.

Y. X. Li, L. H. Wang (2010). A Survey on Bilingual Teaching in Higher Education Institute in the Northeast of China. Journal of Language Teaching and Research, 1(4): 353-357. http://dx.doi.org/10.4304/jltr.1.4.353-357

D. D. Wang, B. L. Yu, et al.. College Mathematics. Xuzhou: China University of Mining and Technology Press, 2007.

W. P. Sun (2009). Participation-Model Didactics for Undergraduates in China. Journal of Beijing University of Aeronautics and Astronautics (social science edition), 2.2.

J. Cuisk(2002). Innovative Techniques for Large-Group Instruction. Virginia: National Science Teachers Association Press.

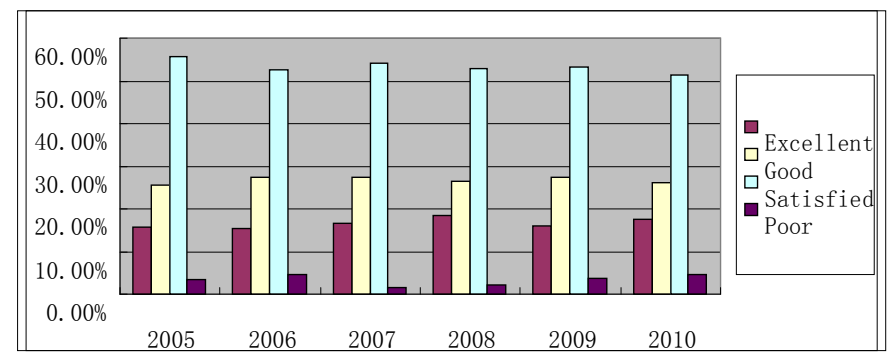

Fig. 1. Percentage of grades in recent years 